\title{
obituary
}

\section{Arend Bouhuys}

AREND BouHUYS died on board the Queen Elizabeth 2, of a sudden and unexpected heart attack, on 15 June 1979, at the early age of 53. He had resigned from his appointment at Yale University and was on his way to Europe to become chairman and professor of the Department of Physiology at the University of Utrecht in his native country.

His untimely death has deprived occupational medicine and respiratory physiology of an active and brilliant research worker who had made an outstanding contribution to environmental lung disease and, in particular, byssinosis or brownlung disease suffered by textile workers.

Bouhuys was born in Deventer, in The Netherlands, in 1925. He graduated MD at Utrecht in 1948. He spent his early years as a resident in internal medicine and chest diseases and as an instructor in physiology. He soon developed a special interest in pulmonary disease and methods of measuring lung function. At the age of 29 he was appointed head of the Pulmonary Function Laboratory at the University of Amsterdam. He had by then become interested in byssinosis and in 1959 he published the first of a series of original papers on effects of cotton, flax, and hemp dust exposure on respiratory symptoms and lung function.

In 1962 he left The Netherlands to take up an appointment in Emory University School of Medicine in Atlanta, Georgia. Two years later he was made a Fellow of the John B. Pierce Foundation in New Haven and was offered an associate professorship at Yale University where, in 1968, he was appointed full Professor of Medicine and Epidemiology. During his 15 years at Yale his output was prolific. He published 86 original research papers, two books on the physiology of breathing and lung disease and numerous review articles and abstracts. In 1975 he became managing editor of Lung which, under his direction, attracted good papers and increased its circulation.

By using computers for recording and analysing respiratory symptoms (by questionnaires) and lung function, he developed sensitive and accurate methods of measuring acute and permanent changes in lung function from exposure to air pollutants. In this way he advanced epidemiological techniques for investigating chronic respiratory disease in communities. His most ambitious study, undertaken by a multidisciplinary team, was of 8,000 community residents in urban and rural districts in Connecticut and a rural population in South Carolina.
Two of his most valuable papers were published a year before he died. One gave new equations based on height, age and weight for predicting normal lung function values in healthy blacks and whites. The other paper was published in Nature 276, 466-471, (1978). It produced evidence from his own and other studies that cigarette smoking and textile dust exposure were far more deleterious to health than out-door air pollution. He concluded that no measurable effects could be expected from further air pollution control with respect to prevalence of chronic bronchitis, asthma and loss of lung function, but, instead, there should be systematic efforts to prevent cigarette smoking and to control exposures to textile dusts and other inhalant risks at work.

In Utrecht he planned to continue research into isolating the causal agent of byssinosis.

If Arend Bouhuys had not been strongly motiviated to apply his considerable skills and energy to the prevention of lung disease, he would have remained a laboratory research worker. Instead, with his co-research workers in various parts of the world, he undertook field studies of textile workers in several countries, including Spain, Holland and the United States. In the U.S. he focussed attention on brown-lung disease, which had been overlooked. His research findings and his own personal commitment helped to establish strict occupational health requirements for US cotton workers through dust control and medical surveillance.

$\mathrm{He}$ is survived by his wife, Fenna, who helped him a great deal in his work, particularly in preparing papers; a son and four daughters, two by a former marriage.

R.S.F.Schilling

\section{P.C. Caldwell}

The Death of Professor P.C. Caldwell FRS, on 6 June 1979 at the age of 52 saddened his many friends and came while he was still at the height of his powers.

$\mathrm{He}$ was born in Warrington and belonged to a family which had lived there for several hundred years and prospered despite suffering heavy penalties for its steadfastness in the Roman Catholic faith. $\mathrm{He}$ was sent to Ampleforth School and there his exceptional academic gifts were recognised but these were so varied that the choice of career proved difficult. He finally decided on a scientific career and went as a scholar to Trinity College, Oxford where he studied physical chemistry for his first degree.
After graduating he stayed in Oxford to do research with Sir Cyril Hinshelwood on nucleic acid in bacteria. Together they showed that DNA per cell mass was related to the rate of growth, and hence protein synthesis, and discussed the need for a relationship between nucleic acid and protein, suggesting that two nucleotides would specify one amino acid. This was the first discussion of the coding problem.

From Oxford Peter Caldwell went to work with Professor A.V. Hill and Sir Bernard Katz at University College, London. It was there that be began his main life's work on the application of physico-chemical methods to biological problems. He made the first successful experiments in which micro-electrodes were used to measure intracellular $p \mathrm{H}$. This led to a whole field of study in which similar electrodes are used to measure intracellular ion activities in vivo. In the course of this work he made the useful discovery that the leg muscles of the crab Maia squinado consisted of very large fibres $1.2 \mathrm{~mm}$ in diameter.

A.V. Hill believed very strongly that physicists and chemists entering biophysics should be sent to a marine biological station and so exposed to a great range of biological material and problems. It was not surprising, therefore, that Caldwell moved next to the Marine Biological Association's Laboratory in Plymouth and there, and at Bristol University, he continued to make key experiments in difficult and very competitive fields of study, often inventing powerful new techniques. With Sir Alan Hodgkin, Professor R.D. Keynes and other colleagues he played a leading role in the spectacular post-war advances in our knowledge of nerve and muscle.

Among the results of his many studies were: the first determinations of ATP, arginine phosphate and orthophosphate in single cells; providing the first example of a spatially orientated enzyme in a living membrane showing different sensitivities to inhibition on its two sides; and finding, on single crab muscle fibres, the first evidence that ionised calcium exists in very low concentrations in cells and that cell activity can be triggered by an increase in this calcium level. At Bristol University he trained a series of postgraduates in research and, with them, made important progress in our knowledge of the influx and efflux of substances from living cells. He was elected FRS in 1975.

Caldwell had many interests to which he gave himself wholeheartedly and in all of these his knowledge was deep and his technical skill so high that he could deal 
with acknowledged experts on equal terms. An excellent pianist, he was devoted to music and composed about 30 piano sonatas. It was in accord with his character that he was especially attracted by the work of composers who, like Schubert, took a theme and followed it through many variations.

Peter Caldwell's exceptionally gentle and kind personality made him much appreciated by a wide circle of friends. When relaxed he was most entertaining company and he was always helpful in the lives and work of his colleagues and students. He will be widely missed and our deepest sympathy goes to Mrs P.A. Caldwell and their children Helen, Margaret, Philip, Anne and Thomas.

E.J. Denton

\section{John Jaeger}

Professor JohN CONRAD JAEger, Emeritus Professor of Geophysics in the Australian National University, died on 15 May 1979 after a long illness, at the age of 71.

Born in Sydney on 30 July 1907, he was educated at the Church of England Grammar School, Sydney, and at the University of Sydney from which he graduated Bachelor of Science in 1928 with first class honours and university medals in mathematics and physics. In that year he went to Cambridge University where he received first class honours in the Mathematical Tripos. Following five years of research at Cambridge in theoretical physics, he joined the University of Tasmania in 1936 as Lecturer in Mathematics, subsequently becoming Professor of Applied Mathematics in that University. In 1942 he was awarded the degree of Doctor of Science in the University of Sydney.

Shortly after the founding of the Australian National University, John Jaeger was invited to accept a Chair and to set up a Department in the Research School of Physical Sciences. He took up his appointment as Professor and Head of the Department of Geophysics in 1952, and remained in that post until his retirement in 1972. Under his direction, the Department of Geophysics developed rapidly into one of the leading research groups of its kind in the world. In 1965, it became the Department of Geophysics and Geochemistry and more recently (1973), was reconstituted to form the Research School of Earth Sciences, at least in part in recognition of the high international reputation that the department established under John Jaeger's leadership.

The direction of development of the deparment was largely based upon his strongly held belief that the application of the basic sciences of mathematics, physics and chemistry, in concert with more conventional geological methods, to the study of the earth, would result in major advances in our understanding of the origin and history of the earth. His recognition of the importance of interdisciplinary fields, together with his ability to attract staff and students, were major factors in establishment of the high reputation of the department, both nationally and internationally, in a relatively short period.

John Jaeger had a most distinguished career as mathematician, physicist and geophysicist. His scientific contributions covered an extraordinarily diverse range of interests, including theoretical physics, radiophysics, ionospheric and solar physics and meteorology, but the main emphasis of his research was in the application of mathematical techniques to a wide variety of theoretical and practical problems, especially the conduction of heat. On establishing the Department of Geophysics in the Australian National University he embarked upon vigorous experimental programmes concerned with heat flow in the Australian continent, and the behaviour of rocks under stress (rock mechanics). John Jaeger was a man of great scholastic achievement; he published more than 130 articles in the scientific literature, and was author or coauthor of six books in applied mathematics and rock mechanics, which are regarded as standard works in their fields. His book (with Carslaw) The Conduction of Heat in Solids is widely accepted as a classic in this area.

In recognition of his achievements, Jaeger, in 1954, was elected a Fellow of the Australian Academy of Science, of which body he was Vice-President in 1958-1959, and in 1970 he was elected Fellow of the Royal Society (London). He was also Doctor of Science (honoris causa) of the University of Tasmania. In 1971, he was awarded the Rankine Lecture by the Institution of Civil Engineers (London).

John Jaeger was a big man, both physically and mentally. He was a man of great humanity but basically very shy. He never sought the limelight and was extremely modest about his own achievements. He set high standards for himself and expected staff and students alike to strive for excellence. His influence in many fields, including the earth sciences, in Australia and indeed in the world, has been profound. He will be sorely missed.

Ian McDougall

\section{J.B. Birks}

DR JOHN B. BIRKS, reader in physics at Manchester University died suddenly on 1 March 1979, a few months after the death of his wife Margaret in a car accident. $\mathrm{He}$ leaves a son and daughter.

He was born on 6 March 1920. After graduation from Oxford in 1940 he joined the Telecommunications Research Establishment for the duration of the war. His work there on radar led to his work on microwave absorption in ferrites, when he joined the Department of Natural Philosophy at Glasgow and for which he received his $\mathrm{PhD}$ in 1947. An interest in scintillation counters led him into the field of scintillators and the photophysics of organic molecules which became his main scientific interest.

In 1951 he became professor of physics at Rhodes University, South Africa, where he quickly established an active research group. However, his dislike of the developing racial policies made him return to Britain in 1954 as diretor of research at British Dielectric Research. In 1957 he moved to Manchester to resume his work on photophysics and in a few years had built up a large and thriving research group which later, with his encouragement, diversified into electron scattering, lasers, microwave spectroscopy, vacuum ultraviolet spectroscopy and latterly, polymer physics.

An empiricist, he was probably most gifted in correlating the mass of data in the field and extracting the essence. He had a good physical insight and made substantial contributions to his subject. A prolific and fluent writer he published some 180 papers, edited the proceedings of many conferences, e.g. the Rutherford Jubilee International Conference 1961, and the series Progress in Dielectrics. $\mathrm{He}$ is probably best known for his books Scintillation Counters (1953), Theory and Practice of Scintillation Counting (1964), Photophysics of Organic Molecules (1970) and the two volumes of Organic Molecular Photophysics (1974). Several monographs on scintillation counting were widely distributed by several companies in the field. He was a consultant to many companies and national laboratories, in demand as a seminar speaker and a great attender of conferences where he met his many friends who will now sadly miss his stimulating presence. An enthusiast for his subject he was on occasions guilty of going a bit over the top but his friends would readily forgive him.

John Birks was a man of wide culture and liberal humanistic views, and was always prepared to defend what he thought was right and to support his friends. Never an establishment man he clashed with authority on several occasions which possibly affected his career. A most efficient and capable administrator, and an excellent teacher and researcher he had much to offer.

He was a generous host who entertained well and was particularly kind to his students, many of whom came from overseas. He made them feel very much at home, and now, spread around the world, they will be saddened by his death.

The loss of his wife was a great blow. They will both be greatly missed by his son and daughter and their families. I am glad that for 28 years I knew him both as friend and colleague.

Scott Hamilton 